\title{
Histone H2B Type F-M
}

National Cancer Institute

\section{Source}

National Cancer Institute. Histone H2B Type F-M. NCI Thesaurus. Code C162837.

Histone H2B type F-M (154 aa, $17 \mathrm{kDa}$ ) is encoded by the human H2BW2 gene. This protein plays a role in nucleosome remodeling. 